\title{
Evaluation of Legionnaires' disease risk and other health hazards at an offset printing company
}

\section{Megan Casey, RN, BSN, MPH}

Brie Hawley, PhD, MS

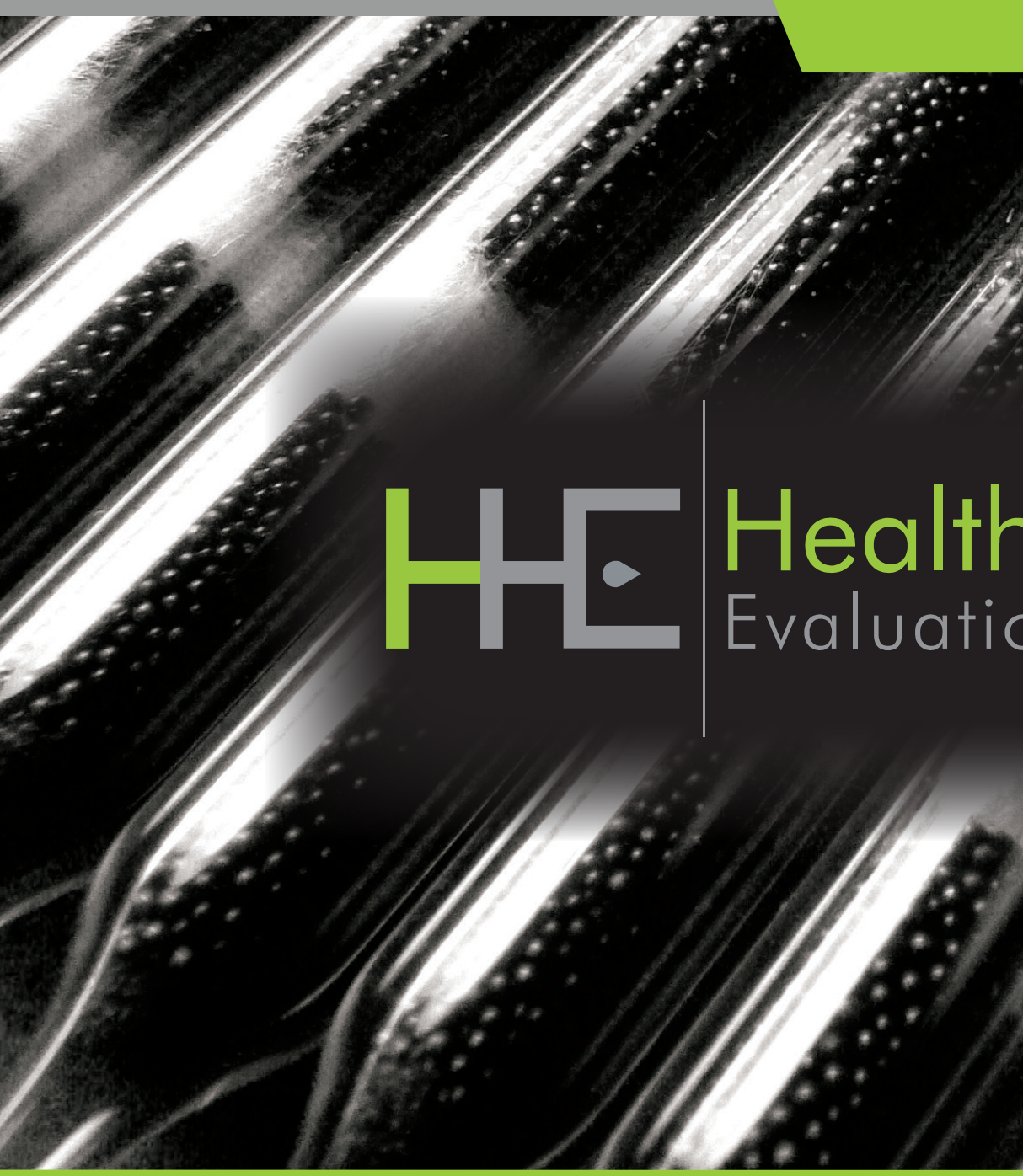

Report No. 2015-0065-3252

April 2016

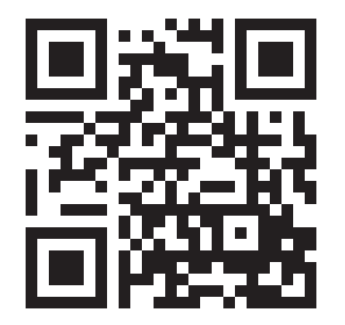

U.S. Department of Health and Human Services Centers for Disease Control and Prevention

National Institute for Occupational Safety and Health

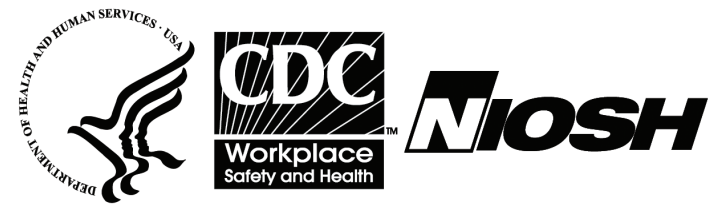




\section{Contents}

Highlights......................................................

Abbreviations .........................................vv

Summary $\ldots \ldots \ldots \ldots \ldots \ldots \ldots \ldots \ldots \ldots \ldots \ldots \ldots \ldots \ldots \ldots \ldots \ldots \ldots \ldots . . . .11$

Introduction .............................................. 2

Process Description ................................ 2

Methods ............................................... 3

Results .............................................. 5

Discussion ..................................... 8

Conclusions................................... 12

Recommendations............................ 12

References......................................... 17

Tables ...................................................... 21

Acknowledgements........................... 28

The employer is required to post a copy of this report for 30 days at or near the workplace(s) of affected employees. The employer must take steps to ensure that the posted report is not altered, defaced, or covered by other material.

The cover photo is a close-up image of sorbent tubes, which are used by the HHE Program to measure airborne exposures. This photo is an artistic representation that may not be related to this Health Hazard Evaluation. 


\section{Highlights of this Evaluation}

In March 2015, Health Hazard Evaluation Program received a confidential employee request for a health hazard evaluation at an offset printing company. Employees described a malfunction in one of the company's air compressors on December 1, 2014, that released a mist into the air. A week after this event, one employee was diagnosed with Legionnaires' disease.

\section{What We Did}

- We made a site visit in April 2015 to informally interview workers and management, tour the facility, and collect samples for Legionella testing.

\section{What We Found}

- All samples were negative for Legionella bacteria.

- After the compressor malfunction, one worker was diagnosed with Legionnaires' disease, and one had flu-like symptoms.

- We could not determine if the compressor malfunction was related to the case of Legionnaires' disease.

- Many solvents and other chemicals were used at this facility. Some of the chemicals are known carcinogens, asthmagens, and sensitizers. Many of the chemicals can have effects on the central nervous system.

- The facility had written policies to limit employees' exposure to chemicals.

- Other than hearing protection, we did not see employees wearing personal protective equipment.

- We saw workers' bare hands in contact with chemicals and solvents while mixing inks and

In response to employee concerns regarding Legionnaires' disease, we interviewed current employees and collected samples for Legionella bacteria at an offset printing company. All samples were negative for Legionella bacteria, which did not provide support for the single case of Legionnaires' disease being workrelated. reaching into chemical tanks.

- English was not the primary language for many employees.

\section{What the Employer Can Do}

- Develop an understanding of the building's water system. 
- Identify and address areas of water stagnation and low-flow.

- Develop and implement maintenance plans for the printing presses and air compressors, according to the manufacturer's specifications.

- Provide long-sleeve uniforms.

- Provide safety glasses, goggles, or face shields to all employees that use any of the chemicals and products listed as mucus membrane irritants, to include: Absolute 6036, Emerald Premium Fountain Solution, General Pressroom Cleaner, Printers Pride Chrome Cylinder Cleaner and Desensitizer, Fountain Concentrate H8DEX, ChillCARE-NR Closed System Treatment, Maricopa Type Wash, Tower MRC, Silicone Spray, 3-36 Bulk, Rapid Blanket Restorer, RD-90, Tech Wash-IF, Aqua-Image Plate Cleaner/Preserver, Roller Shampoo 2011 (VP 187), Arrowev Financial Black, SP200 Subtractive Plate Developer, Kodak Polychrome GRAPHICS Plate Finisher 850S, Kodak Polychrome Graphics Sword Excel Regenerator, Kodak Polychrome Graphics 956 Negative Developer, Kodak SP500B Plus Plate Solution, and Kodak Versamark FD1040 IR Black Ink.

- Provide chemical aprons and gloves to all employees that use any of the chemicals and products listed as capable of passing through the skin, to include: Absolute 6036, Emerald Premium Fountain Solution, General Pressroom Cleaner, Printers Pride Chrome Cylinder Cleaner and Desensitizer, Fountain Concentrate H8DEX, Emerald Premium One-Step Fountain Solution, ChillCARE-NR Closed System Treatment, Rapid Blanket Restorer, RD-90, Tech Wash-IF, Aqua-Image Plate Cleaner/Preserver, Kodak Polychrome Graphics Sword Excel Regenerator, Kodak Polychrome Graphics 956 Negative Developer, Kodak SP500B Plus Plate Solution, and Kodak Versamark FD1040 IR Black Ink.

- Consult with each product's safety data sheet to ensure that chemical aprons and gloves meet the minimum requirements.

- Contact a safety and health professional to perform air sampling for workers' personal exposures to volatile organic compounds in accordance with NIOSH method 2549. If air levels approach or exceed the NIOSH proposed recommended exposure limit or short-term exposure limit for any volatile organic compound, employees should wear respirators with organic vapor cartridges until workplace interventions (e.g., engineering controls, ventilation changes) can reduce air levels, as shown by follow-up air sampling.

- Develop and implement a written respiratory program that meets all regulatory requirements.

- Ensure proper disposal of all chemicals and other waste products.

- Encourage employees to report any new or ongoing respiratory or skin problems.

- Third-party contractors brought in to conduct Legionella bacteria testing or abatement should be told of any suspected or confirmed cases of Legionnaires' disease among workers. 
- Provide signage in additional languages to communicate hazards to employees that do not speak English.

\section{What Workers Can Do}

- Wear personal protective equipment as instructed by your employer.

- Keep chemicals off of your skin.

- Report any new or ongoing respiratory or skin problems to the health and safety official and your physician(s). 
This page left intentionally blank 


\section{Abbreviations}

ACGIH American Conference of Governmental Industrial Hygienists

AOEC Association of Occupational and Environmental Clinics

CDC Centers for Disease Control and Prevention

CFR Code of Federal Regulations

CFU Colony Forming Units

ELITE Environmental Legionella Isolation Techniques Evaluation Program

IARC

International Agency for Research on Cancer

LOD

Level of Detection

$\mathrm{mL}$

Milliliter

NIOSH National Institute for Occupational Safety and Health

OSHA Occupational Safety and Health Administration

PNEAC Printers' National Environmental Assistance Center

PPE Personal Protective Equipment

qPCR Quantitative Polymerase Chain Reaction

REL Recommended Exposure Limit

SDS Safety Data Sheet

STEL Short-term Exposure Limit

VOC Volatile Organic Compound

wt $\% \quad$ Percentage by Weight 


\section{Summary}

The National Institute for Occupational Safety and Health received a confidential request for a health hazard evaluation from employees at a commercial offset printing company. Employees described a malfunction in one of the company's air compressors on December 1, 2014 that released a mist into the air. A week after this event, one employee was diagnosed with Legionnaires' disease.

NIOSH made a site visit to the facility in April 2015. During this visit, NIOSH staff informally interviewed 11 workers, toured the facility, and collected 20 samples for Legionella bacteria testing. Bulk liquid samples and swab samples were taken from several sites throughout the facility including the air compressor, printing presses, hot water tank, and employee restrooms. All bulk fluid and swab samples were negative for the presence of Legionella bacteria. As we did not evaluate all potential sources of Legionella in the facility, we recommend that the company develop an understanding of their building's water system, including identifying areas of water stagnation and low-flow.

Interviewed employees reported no health problems during the compressor malfunction or in the days following the event. We reviewed repair records for the air compressor; however, we could not determine if the compressor malfunction was related to the one diagnosed case of Legionnaires' disease. We recommend that the company develop and implement a maintenance plan for the air compressors and printing presses which may include regular heat and flush or hyper-chlorination of water lines and condensation drains.

During our tour of the facility, we observed many work areas and tasks with the potential for worker exposure to hazardous chemicals. There were many open containers of solvents and chemicals. Other than hearing protection, we did not see employees wearing personal protective equipment. We observed employees with bare hands in contact with chemicals and solvents while mixing inks and reaching into chemical tanks. We saw some hazard communication in different languages. However, pictures were not used in all hazard communication materials and not all hazard communication materials were in languages understood by all workers. We recommend proper storage, containment, and disposal of solvents and chemicals. Additionally, we advise that the facility provide personal protective equipment to all employees and provide education on when personal protective equipment is required. This includes a written respiratory protection plan for employees that meets all regulatory requirements. Signage should be provided in additional languages to communicate hazards to employees that do not speak English.

We could not determine if the air compressor malfunction was related to the single case of Legionnaires' disease. However, employees at this facility were potentially exposed to a number of chemicals and solvents. Although some controls were in place to reduce exposure to chemicals, we noted opportunities for exposure during our site visit that can be addressed through enhanced engineering controls, modified work practices, and improved use of personal protective equipment. 


\section{Introduction}

In March 2015, the National Institute for Occupational Safety and Health (NIOSH) received a confidential employee request for a health hazard evaluation at a commercial printing company. In addition to the corporate headquarters, the company owned four production facilities. The facility that was specified in the health hazard evaluation request produced printed materials using an offset printing technique. Employees described a malfunction in one of the company's air compressors on December 1, 2014, that released a mist into the air. A week after this event, one employee was diagnosed with Legionnaires' disease. NIOSH made a site visit in April 2015 to informally interview workers and management, tour the facility, and collect samples for Legionella testing.

Legionnaires' disease is a respiratory illness caused by the bacteria Legionella. Symptoms include pneumonia, cough, shortness of breath, fever, and sometimes nausea, vomiting, or diarrhea. Legionnaires' disease is treatable with antibiotics. A milder form of infection with Legionella bacteria is called Pontiac Fever which involves similar symptoms but does not progress to pneumonia and does not require treatment [CDC 2015a]. Both diseases are caused by breathing in sprays or mists that contain Legionella bacteria. The incubation period for Legionnaires' disease ranges from 2 to 10 days and for Pontiac Fever from 24 to 72 hours. Sources of Legionella bacteria include almost any warm water system or device that disseminates water as a spray or mist. An estimated 8,000 to 18,000 people need care in a hospital due to Legionnaires' disease each year in the United States [CDC 2015b].

\section{Process Description}

The main production floor was approximately 22,700 square feet and held four lines for offset printing, an area where printed materials were bound, an area for shipping and receiving, four ink tanks, two employee restrooms, and a mezzanine which held the air compressors to run machinery. The building also had an office area, employee break room, and a smaller, separate production area used for ink-jet printing. As of April 2015, there were approximately 33 employees at the facility working two shifts (6 a.m.-2 p.m., 2 p.m.-10 p.m.) Monday through Friday.

The facility produced printed products such as newsletters, mailers, and magazines using an offset printing technique. Offset printing works by transferring an inked image from a plate to a rubber blanket and then onto paper. Color images are separated into primary printing colors (cyan, magenta, yellow, and black), and separate plates are made for each color. When these four primary printing colors are printed onto each other, they come together to reproduce the original, source image.

As a lithographic process, offset printing depends on the repulsion of oil and water. Each printing plate is made with areas that are receptive to oil and areas that are receptive to water. The areas that are receptive to oil hold onto the ink while the areas that are receptive to water repel the ink and remain blank. To help repel ink, a substance called fountain solution is added to the water. Fountain solutions are acidic ( $\mathrm{pH}$ 3.5-5.5) and contain small amounts of buffers, alcohols, surfactants, hydrophilic polymers, complexing agents, and preservatives 
[IARC 1996; Glatfelter Technical Bulletin 2005]. Several different fountain solutions were used by the company. Fountain solutions were held in tanks on the production floor.

In an offset printing press, there are separate printing units for each color of ink. Each printing unit has three main cylinders that rotate at the same surface velocity so that they have contact with each other without sliding. These three cylinders are called the plate cylinder, the blanket cylinder, and the impression cylinder. In each printing unit, a series of rollers applies fountain solution and ink to the plate cylinder. The plate cylinder then presses up against the blanket cylinder which is covered by a rubber sheet called a blanket. The ink for the image transfers from the plate to the blanket and then from the blanket to the paper. The paper is moved through the printing press by an additional set of rollers called impression cylinders [Society for Imaging Science Technology 2015; PNEAC 2013; IARC 1996].

Offset printing includes both coldset and heatset offset printing. Both types of offset printing were used on the production floor at the company. One line was used for coldset offset printing, and three lines were used for heatset offset printing. Coldset printing presses use inks that dry through absorption into the paper and evaporation into the air. These presses do not use dryers or chillers. The company used one coldset ink that contained carbon black and was soy oil based (F\&F Printing Ink Corp, Web Offset Soya Based), which is typical for these types of inks [IARC 1996].

Heatset offset printing uses inks that contain solvents, which evaporate when heated, leaving only resin on the paper. A typical formulation for a heatset ink would include organic pigments (15-25 wt \%), hard resins (25-35 wt \%), soft resins and drying oils (5-15 wt \%), mineral oil (25-40 wt \%), and additives (5-10 wt \%) [Willams 1992; Kübler 1993]. The company used three heatset inks that contained technical white oil or mineral oil (Braden Sutphin Innovation Process). Heatset printing presses use dryers that blow air onto the paper to heat it. The heated paper is then run through a set of chiller rollers which quickly cool the paper. Chiller rollers use temperature controlled water to make them cold [Society for Imaging Science Technology 2015; PNEAC 2013; IARC 1996].

There was no set maintenance plan for the printing presses and repairs were made as needed. Maintenance for the air compressors that ran the printing presses consisted of weekly fluid changes which was done by an employee. Major repairs or maintenance to the air compressors were completed by an outside contractor.

\section{Methods}

\section{NIOSH Site Visit April 2015}

Upon arriving at the facility, we held an opening meeting with management and an employee representative to discuss this health hazard evaluation request and to describe the objectives and activities for our walkthrough visit. We confirmed that our primary aims for the visit were to (1) assess for the potential for Legionella growth in the facility; (2) collect bulk fluid samples and swabs for Legionella testing; (3) informally speak with staff about their work, the events on December 1, 2014, and any related health concerns that they may have; (4) 
learn about the production process and employee tasks; and (5) understand any health and safety practices and programs.

After the opening meeting, we toured the facility starting with the front office area followed by the ink-jet printing area and then the press room. The plant manager led the tour and answered our questions.

After the walkthrough of the facility, a NIOSH staff member moved to the conference room and began confidential interviews with employees. Once employee interviews were completed, members of the management staff were interviewed.

On Friday, April 24, NIOSH staff collected five swab samples and 15 liquid bulk samples of $200 \mathrm{~mL}$ using gloves, $25 \mathrm{~mL}$ pipettes, and sterile bottles (Table 1). Gloves and pipette tubes were changed between each sample to mitigate risk of cross-contamination. Specimens were shipped to NIOSH and stored at $4^{\circ} \mathrm{C}$ until laboratory analyses were performed. On Saturday, April 25, we measured the $\mathrm{pH}$ and chlorine concentration of each bulk sample in a NIOSH laboratory. We tested water samples for free chlorine content and $\mathrm{pH}$ level with a swimming pool chlorine and pH test kit (Model 242-2, Poolmaster, Inc., Sacramento, CA). Free chlorine is the chlorine that is not currently combined with contaminants in the water. On Monday, April 27, the samples were shipped for Legionella testing to Special Pathogens Laboratory in Pittsburgh, PA. This laboratory is proficiency certified through the Centers for Disease Control and Prevention's (CDC) Environmental Legionella Isolation Techniques Evaluation Program (ELITE) [Special Pathogens Laboratory 2016]. Two types of testing were performed to detect Legionella bacteria: bacterial culture, a method of multiplying bacteria by letting them selectively reproduce in a controlled laboratory setting, and quantitative polymerase chain reaction (qPCR), a method that detects genetic fingerprints in the bacteria and then amplifies this genetic material to detect the presence of Legionella bacteria. The Legionella culture limit of detection was approximately 10 colony forming units (CFU) per mL of liquid sample and 20 CFU per swab. The qPCR method will detect both living and dead Legionella cells and is considered to be more sensitive than bacterial culture [Wellinghausen 2001; Behets 2007; Declerck 2006].

At the end of our visit on April 24, we held a closing meeting with the management and an employee representative. We asked management staff to review the digital copies of all photos taken during our visit. Management confirmed that photos did not contain trade secret information or issues of document security. We also requested documents related to the company's health and safety programs and practices, to include (1) the Employee General Safety Manual, (2) the Escalation Policy, (3) the Hazard Communication Plan, (4) the Machine Safe Guarding Policy, (5) the Lockout/Tagout Plan, (6) the Forklift Operation Manual, and (7) the Personal Protective Equipment (PPE) Program.

The NIOSH team requested documents related to maintenance and repairs of the air compressors and the printing presses. We also requested a copy of the Safety Data Sheet (SDS) inventory and asked for copies of all the SDSs for the facility. Additionally, we requested documents to better understand the events on December 1, 2014, to include a list of employees present on that date as well as the number of sick days for the last week of November 
and first and second weeks of December for 2009 to 2014 . We provided a tabular form that management could use to record the number of sick days taken by employees.

\section{Results}

\section{Occupational Safety and Health Administration (OSHA) Investigation}

OSHA was notified of the potential Legionella risk at the facility on December 9, 2014 by an employee. Although no site visit was made, OSHA corresponded with management and asked them to evaluate and eliminate Legionella risks.

\section{Gordon Air Quality}

On December 23, 2014 Gordon Air Quality performed a visual walkthrough inspection of the facility focusing on sources of water as potential reservoirs for Legionella. The inspection found no obvious sources of open water in the production areas. No samples were taken. Gordon Air Quality's final report for this visit, dated December 30, 2014, concluded that if concerns about the presence of Legionella persisted, then a more comprehensive evaluation could be conducted. However, a comprehensive evaluation was only recommended if a person working at the facility was diagnosed with Legionnaires' disease, indicating that Gordon Air Quality was not aware of a diagnosed worker.

\section{NIOSH Evaluation April 2015}

\section{NIOSH Workplace Observations}

We observed many work areas and tasks with the potential for worker exposure to hazardous chemicals. We observed many open containers of solvents and chemicals. Chemical tanks containing fountain solution were open to the air. We observed rags and towels with chemical and solvent residues stored in uncovered waste containers and left on workbenches. We noted spilled chemicals and solvents around the printing presses. We noted many workers had spilled solvents and inks on their uniforms. The uniforms were short-sleeved; skin contact can be a significant route of solvent exposure. We observed ink spilling out of the printing presses onto the floor. The floor around some of the chemical tanks was wet and very slippery around the printing presses. The air in the press room had a strong solvent odor. A microwave and containers of food, located in the press room, suggested that employees prepare and eat foods in the press room, which poses a risk of exposure to workplace chemicals through ingestion.

The company had a spreadsheet for PPE for each department. This plan specified the various tasks that were performed in each department and what PPE is required for each task. We observed some workers with hearing protection. We did not observe any other PPE being worn or made available to employees in the press room. The written company guidelines for PPE indicated that hearing protection is required at all times. The PPE guidelines also stated that employees are required to wear safety glasses, face shields, chemical aprons, heat resistant gloves, and nitrile gloves when performing specific tasks. However, we observed employees' with bare hands in contact with chemicals and solvents while mixing inks and reaching into chemical tanks. 
Many employees had limited English language skills and spoke Spanish, Portuguese, and Vietnamese. We saw some hazard communication in languages other than English. However, pictures were not used in all hazard communication materials and not all hazard communication materials were in languages understood by all workers.

\section{Summary of Employee Interviews}

NIOSH informally interviewed 11 out of 33 (33\%) current employees. Interviewed employees were press operators and roll tenders. Their work tenure at the facility ranged from one to 15 years. Although some employees described health concerns, none felt that their symptoms were related to work or had a work-related pattern. Employees indicated that they would go to the Plant Manager or Human Resources, if they had any health concerns. Several employees stated that they currently smoke cigarettes.

We asked employees to describe the events on December 1, 2014 when an air compressor malfunctioned. Seven out of 11 employees were present on that date. Several employees described that the compressor malfunctioned after the oil was changed as part of weekly maintenance. On Monday, December 1, 2014 an employee responsible for air compressor maintenance added oil to the compressor at roughly 6:00 a.m. In the process of replacing the cap to the oil well, he unknowingly broke the gasket or o-ring sealing the cap. He started the compressor and within several minutes, a white mist was emitted. After realizing that the mist was coming from the compressor, he shut the machine off, identified the broken o-ring, replaced it, and started the compressor again.

Employee descriptions of the compressor malfunction were similar, and all described a white, odorless mist that was emitted from the compressor and moved up towards the ceiling. There were also reports of an oily sheen beneath the compressor. Some employees thought that the mist was smoke from a fire. Employee estimates of how long the mist persisted in the press room ranged from 10 minutes to one hour. Employees reported that there was no evacuation of the affected work area. Interviewed employees reported no health problems during the compressor malfunction or in the days following the event.

Following our visit, we were referred to one additional employee who described "flu-like" symptoms in the week following the compressor malfunction. This individual described general malaise, cough, and congestion, and did not seek care for these symptoms.

In August 2015, NIOSH was notified by several employees that the air compressor had malfunctioned again. We interviewed three employees and spoke with management who confirmed that an o-ring had broken during the oil change and a white mist was released from the compressor.

\section{NIOSH Environmental Sampling}

All bulk fluid and swab samples were negative for the presence of Legionella bacteria. Table 1 describes the results of this testing.

\section{Review of Air Compressor Repair Records}

We received repair records for the air compressor that malfunctioned. It was serviced in September 2014 and June 2015 by an outside contractor. Repair records indicated that an oil 
change, oil filter change, air filter change, external cleaning of the heat exchangers, servicing of scavenger line and screens, cleaning of condensate traps, adjustment of controls, safety device check, air leak check, cleaning of dryer condenser and motor greasing were performed at these times. The contractor was brought in again in August 2015, shortly after the compressor had malfunctioned a second time. During this visit, the oil was changed, new mounts for the oil/water separator were put in, and an oil fill o-ring was replaced. The contractor performed a test-run of the machine and found no additional problems.

\section{Review of OSHA 300 Injury and Illness Logs}

We reviewed OSHA Injury and Illness logs from 2010-2014. Musculoskeletal injuries and hearing loss were the most commonly reported events. The single case of Legionnaires' disease was listed in the $2014 \log$, no other respiratory illnesses were reported.

\section{Review of Reported Sick Days}

We requested the number of sick days taken by employees and the total number of employees for the last week of November and the first two weeks of December for 2009-2014. The company was unable to provide this information for 2009-2012. The number of sick days reported in 2014 did not significantly differ from the number of sick days reported in 2013.

\section{Review of Medical Records}

We reviewed the medical records for one employee with a diagnosis of Legionella. The employee provided NIOSH written informed consent to describe the illness.

\section{Case report}

On Monday, December 1, 2014, a 52-year-old man, who was a current smoker, reported to work at an offset printing company. He had worked as a press operator for 30 years. He arrived to work at 6:00 a.m. Upon entering the press room, he noticed that the air seemed hazy, and a compressor on a mezzanine was releasing a white mist. The mist rose into the air and drifted down to the far end of the press room where his printing press was located. He continued working at his printing press and the mist dissipated after about an hour.

He began feeling nauseated the morning of Wednesday, December 3. On this day, he had to leave work after several hours because of worsening nausea and the onset of vomiting. His symptoms progressed to include fever, chills, non-productive cough, and diarrhea. On Thursday, December 4, he went to his primary care physician and was diagnosed with a gastrointestinal virus and treated with intravenous fluids and an anti-nausea medication.

Despite this treatment, his symptoms worsened, and on Friday, December 5, he went to a local emergency department. On physical exam, he was found to have crackles in his left lower lung field and diffuse wheeze. His oxygen saturation was $93 \%$ on room air, temperature was $100.9^{\circ} \mathrm{F}$ and white blood cell count was elevated (17,000 with $23 \%$ bands). A chest $\mathrm{x}$-ray showed a left lower lobe infiltrate. He was diagnosed with pneumonia and admitted to the hospital and started on intravenous antibiotics.

On Saturday, December 6, an infectious disease physician evaluated the patient and ordered a urine antigen test and a sputum culture for Legionella bacteria. Samples were collected from the patient and sent for laboratory analysis; however, the sputum culture was not performed, 
and no other testing was performed on the sputum sample. The urine antigen test was positive for Legionella, and on Monday, December 8, the patient was diagnosed with Legionnaires' disease.

The patient remained in the hospital on supplemental oxygen via nasal cannula at 5 liters per minute. He had bronchospastic coughing with deep inspiration. A repeat chest x-ray on December 11 showed decreased density of the left lower lobe infiltrate, but a new infiltrate in the right mid-lung. The infectious disease physician concluded that the new infiltrate was due to progression of the disease in the first 48 hours, and the patient continued antibiotic therapy. On December 12, he was discharged from the hospital to a rehabilitation facility for continued treatment and evaluation. On December 19, he was discharged to home.

Although his cough had resolved, he continued to experience shortness of breath with exertion and at rest. He developed a constant tremor which was worse with intention (when reaching for an object) and prevented him from completing fine motor movements. In addition, he felt fatigued, lightheaded, and had problems with his memory. His physician thought these problems were characteristic of Legionella post-infectious syndrome and prevented him from returning to work. He remains out of work and continues to experience fatigue, constant tremor, shortness of breath on exertion as well as depression and anxiety related to his disability.

\section{Discussion}

Only one case of Legionnaires' disease was identified during the course of our investigation. No additional cases of Legionnaires' disease were identified during our interviews with employees and management. The CDC defines an outbreak of Legionnaires' disease to be two or more people (1) exposed to Legionella bacteria and (2) showing symptoms of illness in the same place at about the same time [CDC 2015c]. One additional employee was identified as having malaise, cough and congestion, which is consistent with Pontiac Fever, but also many other diseases [CDC 2015a].

Our investigation could not determine whether this worker was exposed to Legionella bacteria at the workplace, including the air compressor. We did not detect Legionella in the environmental samples taken several months after the compressor malfunction and the employee's diagnosis of Legionnaires' disease. The period of time between the compressor malfunction and the employee's onset of symptoms was roughly 48 hours which is the minimum incubation period for Legionnaires' disease [CDC 2015a]. Our interviews with the employee did not reveal other obvious sources of Legionella bacteria exposure such as hot tubs, fountains, or overnight travel [CDC 2015d]. Confirmation of the source of the employee's illness requires genetic matching between sputum taken at the time of his illness and an environmental sample that was positive for Legionella bacteria [CDC 2015e]. We determined that the sputum collected during the employee's illness had been discarded by the testing laboratory before any genetic matching could be performed. However, none of the environmental samples taken from the workplace were positive for Legionella bacteria, so genetic matching would not have been possible even if the sputum sample was available for testing. Thus, we cannot definitively determine whether the employee was exposed to Legionella bacteria at work. 
Although the diagnosis of one case of Legionnaires' disease does not constitute an outbreak and we cannot confirm that the employee was exposed at work, OSHA recommends that a workplace investigation is conducted, even when only one case of probable or confirmed Legionnaires' disease is recognized [OSHA 2003a]. The company had Gordon Air Quality evaluate the facility on December 23, 2014, roughly two weeks after the worker was diagnosed with Legionnaires' disease. However, the conclusion of the Gordon Air Quality report indicates that they were not aware of an employee diagnosed with Legionnaires' disease. Because they were unaware of any cases of Legionnaires' disease, a comprehensive evaluation was not recommended. The company should have informed Gordon Air Quality of an employee diagnosed with Legionnaires' disease to assure a comprehensive assessment of Legionella risk.

The worker diagnosed with Legionnaires' disease attributed his illness to an air compressor malfunction that released a mist into the air on December 1, 2014. Air compressors have been implicated in Legionnaires' disease outbreaks in healthcare settings and are recommended as a sampling site for Legionella bacteria [Barbaree 1987; WHO 2007]. Descriptions of the air compressor malfunction indicate that there was a white mist that rose into the air and an oily sheen that fell to the floor beneath the air compressor.

Although we do not know the exact composition of the white mist, it is possible that the oily sheen seen under the air compressor was air compressor fluid. The vapor density of the air compressor fluid is greater than air and would be expected to settle onto the floors.

Additionally, we do not know if the mist contained water and Legionella bacteria. Legionella lives and grows in water [CDC 2015f]. The air compressor that malfunctioned was an aircooled, rotary screw air compressor (Kaesar BS-51). The only source of water in this type of air compressor would be due to condensate that develops as air is compressed. Condensate forms in several areas of air compressors including the aftercooler, moisture separator, piping, and the refrigerated air dryer and filters [Scales 2007]. Proper condensate management includes a system for both drainage and condensate treatment. Air compressors can use various types of valves, drains, and reservoirs that need to be maintained in order to drain condensate from the system [Scales 2007]. As lubricant is often present in the condensate, the Environmental Protection Agency, state and local authorities require oil/water separators to be used to reduce the amount of lubricant to within legal limits before being discharged to sewers [CFR Title 40 Part 279; Scales 2007]. Improper condensate management can lead to water backing up into the compressor including the oil reservoir.

Legionella bacteria require water and specific temperatures for growth and survival $\left(68^{\circ}\right.$ $122^{\circ} \mathrm{F}$ ) [OSHA 2003b]. Some strains have been isolated from hot-water systems up to $151^{\circ} \mathrm{F}$, but above $158^{\circ} \mathrm{F}$, they are destroyed almost instantly [Dennis 1984; Dennis 1988]. Review of repair records suggested that the temperature of the air compressor while running would not support Legionella survival. Temperatures recorded for the air compressor ranged from $182^{\circ} \mathrm{F}$ $-184^{\circ} \mathrm{F}$. However, the compressor malfunction occurred when the machine was started on a Monday morning, after being shut-down for the weekend. Growth of Legionella bacteria has been attributable to the start-up of stagnant systems without adequate chemical treatment but not specific to air compressors [Bentham 1993; Falkinham 2015]. Legionella bacteria would 
have had to be introduced into the air compressor after it was shut down on the Friday prior, while the machine still warm enough to promote growth with adequate time for bacterial proliferation.

Without knowing the exact condition of the air compressor on the day of the malfunction, we cannot determine if there was excessive condensate or the potential for Legionella growth. Review of repair and maintenance records indicate that the air compressor was serviced in September 2014 which included fluid and filter changes as well as condensate trap cleaning. Based on the description of the maintenance performed, any problems with condensate management would have been found at this time and addressed by the contractor.

According to the World Health Organization (WHO), large water systems, such as building water systems, are those most commonly associated with human exposure to Legionella bacteria [WHO 2007]. We collected samples for Legionella testing from many water sources in the facility including the air compressor, and all of our tests were negative for the presence of Legionella bacteria. However, Legionella testing results should not be seen as a surrogate for a comprehensive control strategy [Bentham 2002]. Any water system can be a source of Legionella if the water provides conditions that promote growth of the bacteria.

ASHRAE has developed guidance for managing Legionella risks in building water systems. As part of a water management program, ASHRAE recommends that building managers develop an understanding of their potable and non-potable water system and identify where hazardous conditions may occur. The recommended maintenance for potable water includes an inspection of water containing vessels and system components, flushing stagnant and lowflow areas, maintenance and monitoring of equipment based on manufacturer's recommendations, and maintaining and storing maintenance records and operating manuals [ASHRAE 2015].

Many occupational exposures have been observed for workers in the printing industry and include exposures to organic solvents, mineral oils, pigments, resins, paper dust, adhesives, polycyclic aromatic hydrocarbons, acrylates, lead, and noise [Beaulieu 1978; IARC 1996; Michaels 1991]. A study of over 19,000 adults in Denmark found that printing workers were exposed to 300 different substances, 26 of which were known or suspected carcinogens [Lynge 1995]. Because many exposures in the printing industry are known to cause cancer, the International Agency for Research on Cancer (IARC) classified occupational exposures in the printing industry as possibly carcinogenic [IARC 1996]. Studies of printing industry workers have found excesses of lung, bladder, breast, and pancreatic cancer as well as melanoma [IARC 1996; Lynge 1995; Luce 1997; McLaughlin 1988; Dubrow 1986; Leon 1994; Zoloth 1986; Vineis 1985; Aroson 1994]. In 2013, a cluster of printing industry workers in Japan developed bile duct cancer after working in an inappropriately ventilated basement [Yamada 2014, 2015].

Workers in the printing industry have also been observed as having an elevated risk for lung, skin, and nervous system disorders. The prevalence of asthma in adults employed in the printing, publishing, and allied industries was found to be significantly elevated [Bang 2005]. Chemicals used in the printing industry have also been associated with the development 
of allergies and allergic respiratory and skin diseases [Papa 1996; Morgan 2000; Decharat 2014]. Skin problems have also been associated with chemicals used in the printing industry. Plastic monomers, acrylates, polyurethane, and ultra-violet drying acrylics have all been found to be associated with dermatitis in printers [Nethercott 1986; Garabrant 1985; Livesley 2002; Fousserau 1982].

Neurologic symptoms such as neuropathy, reduced perceptual-motor speed, decreased motor steadiness, reduced sense of smell, memory problems, and difficulty sleeping have been found among printing industry workers [Chang 1993; Wang 1986; Yu 2004; Song 2015].

Given the negative health outcomes associated with working in the printing industry, it is important that safeguards are put in place to protect workers. During the site visit, NIOSH observed some work processes and practices that put employees at risk for chemical exposure. Processes and practices noted as having risks for chemical exposures included open containers of chemicals, spilled chemicals, bare hands in contact with chemicals, and inappropriate waste disposal methods. We reviewed the SDS inventory for products in use at this facility and highlight chemicals with potential health effects in Table 2. Many of the chemicals listed Table 2 are volatile organic compounds (VOCs). VOCs are chemicals that evaporate or sublimate into the surrounding air where they can be inhaled by a worker. However, it should be noted that many hazardous compounds are often undisclosed on SDSs for products used in the printing industry [Tsai 2016].

Chemicals found in products on site with known health risks are listed below in Table 2. We list chemicals alongside of their potential to (1) irritate mucus membranes, (2) increase risk for cancer, (3) cause and/or exacerbate asthma, (4) be absorbed across the skin, and (5) affect the central nervous system. The following categories describe a chemical's potential to cause cancer: Group 1: carcinogenic to humans; Group 2A: probably carcinogenic to humans; Group 2B: possibly carcinogenic to humans; Group 3: not classifiable as a carcinogen to humans due to a lack of studies; Group 4: probably not carcinogenic to humans. These groups are based on data published by IARC and the American Conference of Governmental Industrial Hygienists (ACGIH) [IARC 2016, ACGIH 2015]. Additionally, chemicals that increase risk for asthma are described further by their asthmagen type. Asthmagen type is based on data published by the Association of Occupational and Environmental Clinics (AOEC) [AOEC 2012]. We note that respiratory sensitizers are materials that can cause an immune response and adverse respiratory effects, even at low levels of exposure. Further, we note that many of the products in use at this facility are listed on their SDSs as flammable and potentially explosive when stored improperly [Table 2].

PPE is necessary when handling many of the chemicals in use at this facility. For example, dispensing or handling solvents or chemicals found in the etch fluid (Majesta 707), requires the use of face shields, chemical aprons, and 12" butyl or nitrile synthetic rubber gloves. As seen in Table 2, many chemicals in products in use at this facility are able to be absorbed across the skin and require PPE to prevent skin exposures. Although the company had a spreadsheet specifying what PPE should be worn for each department and task, we saw very little PPE being used, outside of hearing protection. PPE and proper ventilation have been shown to reduce the prevalence of symptoms among print industry workers. A 2014 study 
among printing industry workers found that wearing PPE and local ventilation was associated with lower prevalence of eye irritation, rhinitis, and allergic skin reactions [Decharat 2014].

\section{Conclusions}

We could not determine if the air compressor malfunction on December 1, 2014 was related to the single case of Legionnaires' disease. Employees at this facility were potentially exposed to a number of chemicals, including known carcinogens, asthmagens, and sensitizers. Additionally, many of the chemicals are known to irritate mucus membranes and can affect the central nervous system. Although some controls are in place to reduce exposure to chemicals, we noted opportunities for exposure during our site visit that can be addressed through enhanced engineering controls, modified work practices, and improved use of PPE.

\section{Recommendations}

On the basis of our findings, we recommend the actions listed below. We encourage the company to use a health and safety committee or working group to discuss our recommendations and develop an action plan.

Our recommendations are based on an approach known as the hierarchy of controls. The hierarchy of controls groups actions by their ability to effectively reduce or eliminate hazards. In most cases, the preferred approach is to eliminate hazardous materials or processes and install engineering controls to reduce exposure or shield employees. Until such controls are in place, or if they are not effective or feasible, administrative measures, and PPE may be needed.

\section{Elimination and Substitution}

The most effective means of mitigating potential health risks associated with hazardous processes or materials is to eliminate the hazardous processes or materials. When elimination cannot be achieved, substitution with less hazardous materials is advised. Wherever possible, substitute chemicals used for ones with fewer potential health effects. We note that information may not be available about the adverse health effects of many chemicals. Thus, managers should be prepared for the possibility that newly introduced chemicals or combinations of chemicals, even those without documented toxicity, may have unanticipated adverse effects on employees' health. Elimination and substitution should be considered when designing or developing a project and can reduce the need for additional controls in the future.

\section{Engineering Controls}

Engineering controls reduce employees' exposures by removing the hazard from the process or by placing a barrier between the hazard and the employee. Engineering controls protect employees effectively without placing primary responsibility of implementation on the employee. With regard to potential risks from Legionella exposure, we recommend that management:

1. Develop an understanding of the building's water system.

2. Identify and address areas of water stagnation and low-flow. 
3. Develop and implement a maintenance plan for the compressors and printing presses which may include regular heat and flush or hyper-chlorination of water lines and condensation drains. [Check with the manufacturers of your equipment to determine if these methods (heat and flush or hyper-chlorination) would damage the equipment.]

We also recommend the following actions to reduce potential risks from chemical exposures and chemical incompatibilities:

1. Keep containers of solvents and chemicals tightly covered and stored in a designated area.

2. Cover chemical tanks at all times, when not in use.

3. Repair and maintain the printing presses to eliminate leaks.

4. Store combustible waste material and residues (i.e., rags and towels with combustible residues on them) in covered metal receptacles and dispose of daily.

5. Control the pathway of leaks from equipment.

\section{Administrative Controls}

Administrative controls are employer-dictated work practices and policies to reduce or prevent hazardous exposures. The effectiveness of administrative controls depends on employer commitment and employee acceptance. Regular monitoring and reinforcement are necessary to ensure that policies and procedures are followed consistently. We recommend that management:

1. Periodically conduct personal air monitoring for individual VOCs. Because air levels of VOCs may fluctuate from day to day based on production schedules, we recommend personal air sampling for VOCs over multiple days. VOCs should be sampled in accordance with NIOSH Method 2549.

2. If air levels approach or exceed the NIOSH proposed recommended exposure limit (REL) or short-term exposure limit (STEL) for any VOC, employees should wear respirators with organic vapor cartridges until workplace interventions (e.g., engineering controls, ventilation changes) can reduce air levels, as shown by followup air sampling.

3. Maintain and store maintenance logs, records, and operating manuals for all equipment including printing presses and air compressors.

4. Do not allow employees to prepare, eat/drink, or store food in production areas.

5. Encourage employees to always wash hands before eating or smoking.

6. Evaluate federal, state, and local environmental regulations to assure proper disposal of all chemical waste.

7. Implement a smoking cessation program to assist employees to stop smoking.

8. Review the company's emergency evacuation policy to determine if there are clear instructions on when to issue an emergency evacuation and how to perform the evacuation. 
9. Educate employees on the evacuation plan.

10. Encourage employees to immediately clean spills of solvents or other chemicals.

11. Ensure that the drains and traps near the printing presses are routinely cleaned and that the floors are kept as dry as possible.

12. Require that containers that are re-purposed, are relabeled by replacing the original label with new labels that include the date and appropriate waste stream.

13. Ensure that workers understand the hazards associated with working at the printing facility and how to protect themselves. OSHA's Hazard Communication Standard (29 CFR 1910.1200), also known as the "Right to Know Law," requires that employees are informed and trained about potential work hazards and associated safe practices, procedures, and protective measures. Information about OSHA's Hazard Communication Standard can be found at https://www.osha.gov/dsg/hazcom/index. html.

14. Ensure all employees receive initial and annual training on safe work practices. Training should be in language(s) that workers understand.

15. Encourage employees to report any new or ongoing respiratory or skin problems. Consider developing a skin and respiratory surveillance program to identify skin and respiratory conditions that could lead to an occupational disease.

16. If a worker is diagnosed with Legionnaires' disease, OSHA guidance should be followed. [OSHA 2003a]. Third-party contractors brought in to conduct Legionella bacteria testing or abatement should be told of any suspected or confirmed cases of Legionnaires' disease among workers.

\section{Personal Protective Equipment}

Personal protective equipment is the least effective means for controlling hazardous exposures. Proper use of personal protective equipment requires a comprehensive program and a high level of employee involvement and commitment. The right personal protective equipment must be chosen for each hazard. Supporting programs such as training, change-out schedules, and medical assessment are needed. Personal protective equipment should not be the sole method for controlling hazardous exposures. Rather, personal protective equipment should be used until effective engineering and administrative controls are in place.

1. Ensure the PPE guidance document outlines personal protection requirements during chemical handling and cleaning.

2. Provide long-sleeve uniforms and allow workers to change work clothes after a spill or splash.

3. Require that employees wear slip resistant shoes in the press room.

4. Provide safety glasses, goggles, or face shields to all employees that use any of the chemicals and products listed in Table 2 as mucus membrane irritants, to include:

- Absolute 6036 
- Emerald Premium Fountain Solution

- General Pressroom Cleaner

- Printers Pride Chrome Cylinder Cleaner and Desensitizer

- Fountain Concentrate H8DEX

- ChillCARE-NR Closed System Treatment

- Maricopa Type Wash, Tower MRC

- Silicone Spray, 3-36 Bulk

- Rapid Blanket Restorer

- $\mathrm{RD}-90$

- Tech Wash-IF

- Aqua-Image Plate Cleaner/Preserver

- Roller Shampoo 2011 (VP 187)

- Arrowev Financial Black

- SP200 Subtractive Plate Developer

- Kodak Polychrome GRAPHICS Plate Finisher 850S

- Kodak Polychrome Graphics Sword Excel Regenerato

- Kodak Polychrome Graphics 956 Negative Developer

- Kodak SP500B Plus Plate Solution

- Kodak Versamark FD1040 IR Black Ink

5. Provide chemical aprons and gloves to all employees that use any of the chemicals and products listed as capable of passing through the skin. Consult with each product's SDS to ensure that selected chemical aprons and gloves meet the minimum requirements. Products with chemicals capable of passing through the skin include:

- Absolute 6036

- Emerald Premium Fountain Solution

- General Pressroom Cleaner

- Printers Pride Chrome Cylinder Cleaner and Desensitizer

- Fountain Concentrate H8DEX

- Emerald Premium One-Step Fountain Solution

- ChillCARE-NR Closed System Treatment

- Rapid Blanket Restorer

- RD-90

- Tech Wash-IF 
- Aqua-Image Plate Cleaner/Preserver

- Kodak Polychrome Graphics Sword Excel Regenerator

- Kodak Polychrome Graphics 956 Negative Developer

- Kodak SP500B Plus Plate Solution

- Kodak Versamark FD1040 IR Black Ink.

6. Review SDSs to assure that there is proper PPE available for all chemicals at the facility.

7. Specify and document what PPE needs to be worn for each task performed.

8. Review the written PPE guidance with all employees.

9. Develop and implement a written respiratory protection plan for employees that meet all regulatory requirements specified under OSHA's Respiratory Protection Standard 29 CFR 1910.134.

10. If follow-up air sampling highlights air levels that approach or exceed the NIOSH REL or STEL for any VOC, employees should wear respirators with organic vapor cartridges until workplace interventions (e.g., engineering controls, ventilation changes) can reduce air levels, as shown by follow-up air sampling.

11. Ensure PPE is easily available to workers.

12. Install showers, if feasible, so employees can shower and change clothes at the end of their work shift. 


\section{References}

ACGIH (American Conference of Governmental Industrial Hygienists) [2015]. 2015 TLVs®

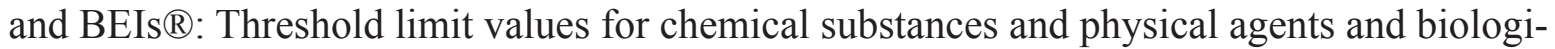
cal exposure indices. Cincinnati, $\mathrm{OH}$ : American Conference of Governmental Industrial Hygienists.

AOEC (Association of Occupational and Environmental Clinics) [2012]. Description of the AOEC exposure code system [http://www.aoecdata.org/]. Date accessed: April 2016

Aroson K, Howe G [1994]. Utility of a surveillance system to detect associations between work and cancer among women in Canada, 1965-1991. J Occup Med 36:1174-1179.

ASHRAE [2015]. Standard 188-2015 -- Legionellosis: risk management for building water systems. ASHRAE. Atlanta, GA.

Bang KM, Hnizdo E, Doney B [2005]. Prevalence of asthma by industry in the US population: a study of 2001 NHIS data. Am J Ind Med 47(6):500-508.

Barbaree JM, Gorman GW, Martin WT, Fields BS, Morrill WE [1987]. Protocol for sampling environmental sites for legionellae. Appl Environ Microbiol 53(7): 1454-1458.

Beaulieu HJ [1978]. Newspaper production is plagued by excessive noise and aerosols. Occup Health Saf 47(5):62-64, 66, 69-70.

Behets J, Declerck P, Delaedt Y, Creemers B, Ollevier F [2007]. Development and evaluation of a Taqman duplex real-time PCR quantification method for reliable enumeration of Legionella pneumophila in water samples. J Microbiol Methods 68(1):137-144.

Bentham RH, Broadbent CR [1993]. A model for autumn outbreaks of Legionnaires' disease associated with cooling towers, linked to system operation and size. Epidemiol Infect 111(2):287-295.

Bentham R [2002]. Routine sampling and the temporal variation of Legionella spp. Concentrations in cooling tower water systems. In: Marre R et al., eds. Legionella: proceedings of the 5th conference on Legionella. Washington DC, American Society for Microbiology, pp.321-324.

Chang CM, Yu CW, Fong KY, Leung SY, Tsin TW, Yu YL, Cheung TF, Chan SY [1993]. Nhexane neuropathy in offset printers. J Neurol Neurosurg Psychiatry 56(5): 538-542.

CDC (Centers for Disease Control and Prevention) [2015a]. Legionella (Legionnaires' disease and Pontiac fever): clinical features [http://www.cdc.gov/legionella/clinicians/clinical-features. $\underline{h t m l}$. Date accessed: April 2016.

CDC [2015b]. Legionella (Legionnaires' disease and Pontiac fever): fast facts [http://www.cdc. gov/legionella/fastfacts.html]. Date accessed: April 2016.

CDC [2015c]. Legionella (Legionnaires' disease and Pontiac fever): surveillance and reporting [http://www.cdc.gov/legionella/surv-reporting.html]. Date accessed: April 2016. 
CDC [2015d]. Legionella (Legionnaires' disease and Pontiac fever): investigation tools for single cases of disease [http://www.cdc.gov/legionella/health-depts/inv-tools-single/index.html]. Date accessed: April 2016.

CDC [2015e]. Legionella (Legionnaires' disease and Pontiac fever): diagnostic testing [http:// www.cdc.gov/legionella/clinicians/diagnostic-testing.html]. Date accessed: April 2016.

CDC [2015f]. Legionella (Legionnaires' disease and Pontiac fever): Causes and transmission [http://www.cdc.gov/legionella/about/causes-transmission.html]. Date accessed: April 2016.

CFR (Code of Federal Regulations). Washington, DC: U.S. Government Printing Office, Office of the Federal Register.

Decharat S [2014]. Prevalence of acute symptoms among workers in printing factories. Adv Prev Med 2014:854052. doi: 10.1155/2014/854052. Epub 2014 Oct 16.

Declerck P, Behets J, Lammertyn E, Lebeau I, Anne J, Ollevier F [2006]. Detection and quantification of Legionella pneumophila in water samples using competitive PCR. Can. J. Microbiol 52:584-590.

Dennis P, Green D, Jones B [1984]. A note on the temperature tolerance of Legionella. J Appl Bacteriol 56(2):349-50.

Dennis P, Lee J [1988]. Differences in aerosol survival between pathogenic and non-pathogenic strains of Legionella pneumophila serogroup 1. J. Appl. Bacteriol 65(2):135-141.

Dubrow R [1986]. Malignant melanoma in the printing industry. Am J Ind Med 10(2):119126.

Falkinham J [2015]. Common features of opportunistic premise plumbing pathogens. Int J Environ Res Public Health 12(5):4533-45.

Foussereau J, Benezera C, Maibach HI, et al. [1982] Occupational contact dermatitis. In: Clinical and chemical aspects. Paris, France: Masson \& Cie.

Garabrant D [1985]. Dermatitis from aziridine hardener in printing ink. Contact Dermatitis 12(4):209-212.

Glatfelter Corporation [2005]. Technical bulletin: fountain solutions, $\mathrm{pH}$ and conductivity. Issue 2005-1 [http://www.glatfelter.com/files/products/carbonless/Fountain_Solutions.pdf]. Date accessed: April 2016.

IARC (International Agency for Research on Cancer) [1996]. Printing processes and printing inks: carbon black and some nitro compounds, vol. 65, IARC Monographs on the Evaluation of the Carcinogenic Risks to Humans, World Health Organization, Lyon, France.

IARC [2016]. IARC Monographs on the evaluation of the carcinogenic risks to humans, World Health Organization, Lyon, France [http://monographs.iarc.fr/ENG/Classification/]. Date accessed: April 2016. 
Kübler R [1993]. Printing inks. In: Elvers B, Hawkins S, Russey W, Schulz G, eds. Ullmann's Eneyclopedia of industrial chemistry. 5th rev. ed., Vol. A22, New York: VCH Publishers, pp.143156.

Leon DA [1994]. Mortality in the British printing industry: a historical cohort study of trade union members in Manchester. Occup Environ Med 51(2):79-86.

Livesley EJ, Rushton L, English JS, Williams HC [2002]. The prevalence of occupational dermatitis in the UK printing industry. Occup Environ Med 59(7):487-492.

Luce D, Landre MF, Clavel T, Limousin I, Dimerman S, Moulin JJ [1997]. Cancer mortality among magazine printing workers. Occup Environ Med 54(4):264-267.

Lynge E, Rix BA, Villadsen E, Andersen I, Hink M, Olsen E, Møller UL, Silfverberg E [1995]. Cancer in printing workers in Denmark. Occup Environ Med 52(11):738-744.

McLaughlin JK, Malker HS, Blot WJ, Ericsson JL, Gemne G, Fraumeni JF Jr. [1988]. Malignant melanoma in the printing industry. Am J Ind Med 13(2):301-304.

Michaels D, Zoloth SR, Stern FB [1991]. Does low-level lead exposure increase risk of death? A mortality study of newspaper printers. Int J Epidemiol 20(4):978-983.

Morgan VA, Fewings JM [2000]. 1,6-hexanediol diacrylate: a rapid and potent sensitizer in the printing industry. Australas J Dermatol 41(3):190-192.

Nethercott JR, Nosal R [1986]. Contact dermatitis in printing tradesmen. Contact Dermatitis 14(5):280-287.

OSHA (Occupational Safety \& Health Administration) [2003a]. Legionnaires' disease e-tool: Section III: How to determine if a workplace is experiencing an outbreak [https://www.osha.gov/ dts/osta/otm/legionnaires/investigation.html]. Date accessed: April 2016.

OSHA [2003b]. Legionnaires' disease e-tool: facts and frequently asked questions [https://www. osha.gov/dts/osta/otm/legionnaires/faq.html]. Date accessed: April 2016.

Papa G, Quaratino D, di Fonso M, Giuffreda F, Romano A, Venuti A [1996]. Allergic respiratory diseases and environmental pollution: experience in the printing/paper-manufacturing industry. Allergy 51(11):833-836.

PNEAC (Printers' National Environmental Assistance Center) [2013]. Print process descriptions: print industry overview [http://www.pneac.org/index.cfm]. Date accessed: April 2016.

Scales B, McCulloch D [2007]. Best practices for compressed air systems, 2nd ed. Alexandria, VA : The Compressed Air Challenge.

Special Pathogens Laboratory [2016]. Accreditations and proficiency [http://www.specialpathogenslab.com/accreditations-and-proficiency.php]. Date accessed: April 2016.

Society for Imaging Science and Technology [2015]. How a printing press works [http://www. imaging.org/site/IST/Resources/Imaging_Tutorials/How_a_Printing_Press_Works/IST/Resources/Tutorials/Printing_Press.aspx?hkey=6e050e2f-5726-4290-a635-12c39f67a296]. Date accessed: April 2016. 
Song H, Tak-Sun Yu I, Qian Lao X [2015]. Neurobehavioral effects of occupational exposure to organic solvents among male printing workers in Hong Kong. Arch Environ Occup Health 70(3):147-153.

Tsai C, Mao IF, Ting JY, Young CH, Lin JS, Li WL [2016]. Quality of chemical safety information in printing industry. Ann Occup Hyg 60(3):361-370.

Vineis P, Magnani C [1985]. Occupation and bladder cancer in males: a case-control study. Int J Cancer 35(5):599-606.

Wang JD, Chang YC, Kao KP, Huang CC, Lin CC, Yeh WY [1986]. An outbreak of Nhexane induced polyneuropathy among press proofing workers in Taipei. Am J Ind Med 10(2):111-118.

Wellinghausen N, Frost C, Marre R [2001]. Detection of legionellae in hospital water samples by quantitative real-time LightCycler PCR. Appl Environ Microbiol 67(9):3985-3993.

Williams CH [1992]. The printer's ink handbook. Beccles, United Kingdom: Maclean Hunter Ltd., Hertfordshire.

WHO (World Health Organization) [2007]. Legionella and the prevention of legionellosis. Geneva, Switzerland. World Health Organization Press.

Yu IT, Lee N, Zhang XH, Chen WQ, Lam YT, Wong TW [2004]. Occupational exposure to mixtures of organic solvents increases the risk of neurological symptoms among printing workers in Hong Kong. J Occup Environ Med 46(4):323-330.

Yamada K, Kumagai S, Nagoya T, Endo G [2014]. Chemical exposure levels in printing workers with cholangiocarcinoma. J Occup Health 56(5):332-338.

Yamada K, Kumagai S, Kubo S, Endo G [2015]. Chemical exposure levels in printing and coating workers with cholangiocarcinoma (third report). J Occup Health 57(6):565-571.

Zoloth SR, Michaels DM, Villalbi JR, Lacher M [1986]. Patterns of mortality among commercial pressmen. J Natl Cancer Inst 76(6):1047-1051. 


\section{Tables}

Table 1. Testing results for bulk fluid and swab samples collected on April 24, 2015

\begin{tabular}{|c|c|c|c|c|c|c|}
\hline $\begin{array}{l}\text { Sample } \\
\text { ID }\end{array}$ & $\begin{array}{l}\text { Sample } \\
\text { Type }\end{array}$ & Location & pH & Cl & $\begin{array}{c}\text { Legionella Test- } \\
\text { ing by Bacterial } \\
\text { Culture }\end{array}$ & $\begin{array}{c}\text { Legionella Testing by } \\
\text { Real-Time quantitative } \\
\text { Polymerase Chain-Reac- } \\
\text { tion (qPCR) }\end{array}$ \\
\hline 01-A & Bulk Fluid & $\begin{array}{l}\text { Community Water Tank } \\
\text { (Reverse Osmosis System) }\end{array}$ & 6.8 & $<\mathrm{LOD}$ & Not Detected & Not Detected \\
\hline 02-A & Swab & $\begin{array}{l}\text { Goss Press: Press Fluid } \\
\text { Plastic Bin Submerged in } \\
\text { Community Water }\end{array}$ & N/A & $\mathrm{N} / \mathrm{A}$ & Not Detected & Not Detected \\
\hline $03-\mathrm{A}$ & Swab & $\begin{array}{l}\text { Goss Press: Press Fluid } \\
\text { Plastic Bin Submerged in } \\
\text { Deionized Water }\end{array}$ & N/A & N/A & Not Detected & Not Detected \\
\hline 04-A & Bulk Fluid & Hantscho Press Fluid & 4.5 & $<\mathrm{LOD}$ & Not Detected & Not Detected \\
\hline 05-A & Bulk Fluid & Baker Press Fluid & 4.5 & $<\mathrm{LOD}$ & Not Detected & Not Detected \\
\hline 06-A & Bulk Fluid & $\begin{array}{l}\text { Baker Press, Wastewater } \\
\text { (Overflow Water) }\end{array}$ & $\begin{array}{l}\text { Not } \\
\text { Done }\end{array}$ & $\begin{array}{l}\text { Not } \\
\text { Done }\end{array}$ & Not Detected & Not Detected \\
\hline $07-\mathrm{A}$ & Bulk Fluid & Harris Press Fluid & 4.2 & $<\mathrm{LOD}$ & Not Detected & Not Detected \\
\hline 08-A & Bulk Fluid & $\begin{array}{l}\text { Sink by Hantscho Press, hot } \\
\text { water tap }\end{array}$ & 7.4 & $<\mathrm{LOD}$ & Not Detected & Not Detected \\
\hline 09-A & Bulk Fluid & $\begin{array}{l}\text { Mens' Restroom sink, hot } \\
\text { water tap }\end{array}$ & 7.4 & $<\mathrm{LOD}$ & Not Detected & Not Detected \\
\hline $10-\mathrm{A}$ & Swab & $\begin{array}{l}\text { Drain sample from drain } \\
\text { in Men's Restroom by } \\
\text { Hantscho Press }\end{array}$ & N/A & $\mathrm{N} / \mathrm{A}$ & Not Detected & Not Detected \\
\hline $11-\mathrm{A}$ & Bulk Fluid & Hot Water Tank & 7.4 & $<\mathrm{LOD}$ & Not Detected & Not Detected \\
\hline $12-\mathrm{A}$ & Bulk Fluid & Press Wastewater \#1 & $\begin{array}{l}\text { Not } \\
\text { Done }\end{array}$ & $\begin{array}{l}\text { Not } \\
\text { Done }\end{array}$ & Not Detected & Not Detected \\
\hline $13-\mathrm{A}$ & Bulk Fluid & Press Wastewater \#2 & 4.3 & $<$ LOD & Not Detected & Not Detected \\
\hline $14-\mathrm{A}$ & Bulk Fluid & Press Wastewater \#3 & 4.5 & $<\mathrm{LOD}$ & Not Detected & Not Detected \\
\hline $15-\mathrm{A}$ & Bulk Fluid & Press Wastewater \#4 & $\begin{array}{l}\text { Not } \\
\text { Done }\end{array}$ & $\begin{array}{l}\text { Not } \\
\text { Done }\end{array}$ & Not Detected & Not Detected \\
\hline $16-\mathrm{A}$ & Swab & $\begin{array}{l}\text { Kaeser BS51 Compressor } \\
\text { Drain Line \#1 }\end{array}$ & N/A & N/A & Not Detected & Not Detected \\
\hline $17-\mathrm{A}$ & Swab & $\begin{array}{l}\text { Kaeser BS51 Compressor } \\
\text { Drain Line \#2 }\end{array}$ & N/A & N/A & Not Detected & Not Detected \\
\hline $18-\mathrm{A}$ & Bulk Fluid & Chiller by Baker Press & 7.6 & $<\mathrm{LOD}$ & Not Detected & Not Detected \\
\hline $19-\mathrm{A}$ & Bulk Fluid & $\begin{array}{l}\text { Mens' Restroom by Bind- } \\
\text { ery, hot water tap }\end{array}$ & 7.7 & $<\mathrm{LOD}$ & Not Detected & Not Detected \\
\hline 20-A & Bulk Fluid & $\begin{array}{l}\text { Laboratory Blank (Deion- } \\
\text { ized Water) }\end{array}$ & 7.4 & $<\mathrm{LOD}$ & Not Detected & Not Detected \\
\hline
\end{tabular}

Notes: $\mathrm{Cl}=$ chlorine; $\mathrm{N} / \mathrm{A}=$ Testing not applicable for this type of sample; $<\mathrm{LOD}=$ The amount of chlorine in the sample was below the level of detection of 0.6 parts per million. 
Table 2. Potential health hazards of chemicals found on safety data sheets

\begin{tabular}{|c|c|c|c|c|c|c|c|}
\hline Chemical & $\begin{array}{l}\text { Mucus } \\
\text { Membrane } \\
\text { Irritation }\end{array}$ & $\begin{array}{c}\text { Carcinogen } \\
\text { Rating* }\end{array}$ & $\begin{array}{c}\text { Asthmagen } \\
\text { Type } \dagger\end{array}$ & Skin & $\begin{array}{c}\text { CNS } \\
\text { Effects }\end{array}$ & $\begin{array}{l}\text { Explosive } \\
\text { Hazard }\end{array}$ & Where Found \\
\hline $\begin{array}{l}\text { 2-butoxy } \\
\text { Ethanol }\end{array}$ & Y & Group 3 & $\begin{array}{l}\text { Respiratory } \\
\text { Sensitizer§ }\end{array}$ & Y & Y & $\begin{array}{l}\text { Can form } \\
\text { explosive per- } \\
\text { oxides when } \\
\text { exposed to air }\end{array}$ & $\begin{array}{l}\text { Absolute 6036, } \\
\text { Emerald Premium } \\
\text { Fountain Solution, } \\
\text { General Pressroom } \\
\text { Cleaner, Print- } \\
\text { ers Pride Chrome } \\
\text { Cylinder Cleaner } \\
\text { and Desensitizer, } \\
\text { Fountain Concen- } \\
\text { trate H8DEX }\end{array}$ \\
\hline Acetic Acid & Y & - & $\begin{array}{l}\text { Respiratory } \\
\text { Sensitizer§ } \\
\text { and RADS }\end{array}$ & - & - & $\begin{array}{c}\text { Explosive } \\
\text { vapor/air } \\
\text { mixtures can } \\
\text { be formed at }> \\
\quad 39^{\circ} \mathrm{C} \\
\end{array}$ & $\begin{array}{l}\text { Emerald Premium } \\
\text { One-Step Fountain } \\
\text { Solution }\end{array}$ \\
\hline $\begin{array}{l}\text { Ammonium } \\
\text { nitrate }\end{array}$ & Y & - & - & $\mathrm{Y}$ & - & $\begin{array}{l}\text { May explode } \\
\text { under high } \\
\text { temperatures } \\
\text { or confine- } \\
\text { ment } \\
\end{array}$ & $\begin{array}{l}\text { Emerald Premium } \\
\text { One-Step Fountain } \\
\text { Solution }\end{array}$ \\
\hline Gum Arabic & Y & - & $\begin{array}{l}\text { Respiratory } \\
\text { Sensitizer§ }\end{array}$ & - & - & - & $\begin{array}{l}\text { Emerald Premium } \\
\text { One-Step Fountain } \\
\text { Solution }\end{array}$ \\
\hline $\begin{array}{l}\text { Sodium } \\
\text { tetraborate }\end{array}$ & Y & - & - & Y & Y & - & $\begin{array}{l}\text { ChillCARE-NR } \\
\text { Closed System } \\
\text { Treatment }\end{array}$ \\
\hline Acetone & Y & Group 3 & - & - & Y & $\begin{array}{c}\text { Vapor/air } \\
\text { mixtures may } \\
\text { be explosive }\end{array}$ & $\begin{array}{l}\text { Maricopa Type } \\
\text { Wash, Tower MRC }\end{array}$ \\
\hline $\begin{array}{l}\text { Petroleum } \\
\text { Naptha } \\
\text { (Petroleum } \\
\text { Distillate) }\end{array}$ & Y & Group 3 & - & - & Y & Combustible & $\begin{array}{l}\text { Maricopa Type } \\
\text { Wash, Sprayway } \\
\text { Silicone Spray, } \\
\text { Tower MRC, 3-36 } \\
\text { Bulk } \\
\end{array}$ \\
\hline $\begin{array}{l}\text { Methylene } \\
\text { Chloride }\end{array}$ & Y & Group 2A & - & Y & Y & Combustible & $\begin{array}{l}\text { Rapid Blanket } \\
\text { Restorer }\end{array}$ \\
\hline $\begin{array}{l}\text { Mineral } \\
\text { Spirits }\end{array}$ & Y & - & - & Y & Y & $\begin{array}{l}\text { Explosive } \\
\text { vapor/air } \\
\text { mixtures can } \\
\text { be formed at }> \\
\quad 21^{\circ} \mathrm{C}\end{array}$ & $\begin{array}{l}\text { RD-90, Tech Wash- } \\
\text { IF, Printers Pride } \\
\text { Chrome Cylinder } \\
\text { Cleaner and Desen- } \\
\text { sitizer, Aqua-Image } \\
\text { Plate Cleaner/Pre- } \\
\text { server }\end{array}$ \\
\hline Propane & - & - & - & - & $\mathrm{Y}$ & Combustible & RD-90 \\
\hline
\end{tabular}


Table 2. Potential health hazards of chemicals found on safety data sheets (con't)

\begin{tabular}{|c|c|c|c|c|c|c|c|}
\hline Chemical & $\begin{array}{c}\text { Mucus } \\
\text { Membrane } \\
\text { Irritation }\end{array}$ & $\begin{array}{c}\text { Carcinogen } \\
\text { Rating* }\end{array}$ & $\begin{array}{c}\text { Asthmagen } \\
\text { Type } \dagger\end{array}$ & Skint & $\begin{array}{l}\text { CNS } \\
\text { Effects }\end{array}$ & $\begin{array}{l}\text { Explosive } \\
\text { Hazard }\end{array}$ & Where Found \\
\hline Heptane & Y & - & - & - & Y & $\begin{array}{l}\text { Vapor/air } \\
\text { mixtures may } \\
\text { be explosive }\end{array}$ & Tower MRC \\
\hline $\begin{array}{l}\text { Nonylphenol } \\
\text { Polyethylene } \\
\text { Glycol Ether }\end{array}$ & Y & - & - & - & - & - & Tech Wash-IF \\
\hline Xylene & Y & Group 3 & - & - & Y & $\begin{array}{c}\text { Explosive } \\
\text { vapor/air } \\
\text { mixtures can } \\
\text { be formed at }> \\
\quad 27^{\circ} \mathrm{C}\end{array}$ & Tech Wash-IF \\
\hline Cumene & Y & - & - & - & Y & $\begin{array}{c}\text { Explosive } \\
\text { vapor/air } \\
\text { mixtures can } \\
\text { be formed at }> \\
\quad 31^{\circ} \mathrm{C}\end{array}$ & Tech Wash-IF \\
\hline $\begin{array}{l}\text { Ethyl Ben- } \\
\text { zene }\end{array}$ & Y & Group 2B & - & - & Y & $\begin{array}{l}\text { Highly flam- } \\
\text { mable }\end{array}$ & Tech Wash-IF \\
\hline $\begin{array}{l}\text { Ethylene } \\
\text { Glycol }\end{array}$ & Y & Group 3 & - & - & Y & Combustible & $\begin{array}{l}\text { Printers Pride } \\
\text { Chrome Cylinder } \\
\text { Cleaner and De- } \\
\text { sensitizer, Fountain } \\
\text { Concentrate H8DEX }\end{array}$ \\
\hline $\begin{array}{l}\text { Propylene } \\
\text { Glycol }\end{array}$ & Y & - & - & - & $\mathrm{Y}$ & Combustible & $\begin{array}{l}\text { Fountain Concen- } \\
\text { trate H8DEX }\end{array}$ \\
\hline $\begin{array}{l}\text { Ammonium } \\
\text { Nitrate }\end{array}$ & Y & - & - & Y & - & $\begin{array}{l}\text { Vapor/air } \\
\text { mixtures may } \\
\text { be explosive }\end{array}$ & $\begin{array}{l}\text { Fountain Concen- } \\
\text { trate H8DEX }\end{array}$ \\
\hline $\begin{array}{l}\text { Organophos- } \\
\text { phonic Acid }\end{array}$ & Y & - & - & - & Y & - & $\begin{array}{l}\text { Roller Shampoo } \\
2011 \text { (VP 187) }\end{array}$ \\
\hline $\begin{array}{l}\text { Isophthalic } \\
\text { Acid }\end{array}$ & - & - & - & - & - & Combustible & $\begin{array}{l}\text { Arrowev Financial } \\
\text { Black }\end{array}$ \\
\hline $\begin{array}{l}\text { Pentaeryth- } \\
\text { ritol }\end{array}$ & Y & - & - & - & - & Combustible & $\begin{array}{l}\text { Arrowev Financial } \\
\text { Black }\end{array}$ \\
\hline $\begin{array}{l}\text { Benzyl Al- } \\
\text { cohol }\end{array}$ & Y & - & - & - & - & Combustible & $\begin{array}{l}\text { SP200 Subtractive } \\
\text { Plate Developer }\end{array}$ \\
\hline
\end{tabular}


Table 2. Potential health hazards of chemicals found on safety data sheets (con't)

\begin{tabular}{|c|c|c|c|c|c|c|c|}
\hline Chemical & $\begin{array}{c}\text { Mucus } \\
\text { Membrane } \\
\text { Irritation }\end{array}$ & $\begin{array}{l}\text { Carcinogen } \\
\text { Rating* }\end{array}$ & $\begin{array}{c}\text { Asthmagen } \\
\text { Type } \dagger\end{array}$ & Skin & $\begin{array}{c}\text { CNS } \\
\text { Effects }\end{array}$ & $\begin{array}{l}\text { Explosive } \\
\text { Hazard }\end{array}$ & Where Found \\
\hline $\begin{array}{l}\text { Sodium } \\
\text { Bisulfite }\end{array}$ & Y & Group 3 & - & - & - & - & $\begin{array}{l}\text { SP200 Subtractive } \\
\text { Plate Developer }\end{array}$ \\
\hline $\begin{array}{l}\text { Pyrophos- } \\
\text { phoric Acid }\end{array}$ & Y & - & - & - & Y & - & $\begin{array}{l}\text { SP200 Subtractive } \\
\text { Plate Developer }\end{array}$ \\
\hline $\begin{array}{l}\text { Phosphoric } \\
\text { Acid }\end{array}$ & Y & - & - & - & - & - & $\begin{array}{l}\text { Aqua-Image Plate } \\
\text { Cleaner/Preserver }\end{array}$ \\
\hline $\begin{array}{l}\text { Sodium } \\
\text { Hexameta- } \\
\text { phosphate }\end{array}$ & Y & - & - & - & Y & - & $\begin{array}{l}\text { Aqua-Image Plate } \\
\text { Cleaner/Preserver }\end{array}$ \\
\hline $\begin{array}{l}\text { Aluminum } \\
\text { Nitrate }\end{array}$ & Y & Group 3 & - & - & Y & - & $\begin{array}{l}\text { Aqua-Image Plate } \\
\text { Cleaner/Preserver }\end{array}$ \\
\hline $\begin{array}{l}\text { Sodium 2-bi- } \\
\text { phenylate }\end{array}$ & Y & Group 2B & - & - & - & - & $\begin{array}{l}\text { Kodak Polychrome } \\
\text { GRAPHICS Plate } \\
\text { Finisher } 850 \text { S }\end{array}$ \\
\hline $\begin{array}{l}\text { Diethanol- } \\
\text { amine }\end{array}$ & Y & Group 2B & $\begin{array}{l}\text { Respiratory } \\
\text { Sensitizer } \S\end{array}$ & $Y$ & - & - & $\begin{array}{l}\text { Kodak Polychrome } \\
\text { Graphics Sword } \\
\text { Excel Regenerator, } \\
\text { Kodak Polychrome } \\
\text { Graphics 956 } \\
\text { Negative Developer, } \\
\text { Kodak SP500B Plus } \\
\text { Plate Solution } \\
\end{array}$ \\
\hline $\begin{array}{l}\text { 2-Phenoxy- } \\
\text { ethanol }\end{array}$ & Y & Group 3 & - & Y & $\mathrm{Y}$ & Combustible & \begin{tabular}{|l} 
Kodak Polychrome \\
Graphics Sword \\
Excel Regenerator, \\
Kodak Polychrome \\
Graphics 956 \\
Negative Developer, \\
Kodak SP500B Plus \\
Plate Solution
\end{tabular} \\
\hline $\begin{array}{l}\text { Sodium octyl } \\
\text { sulfate }\end{array}$ & Y & - & - & Y & - & - & \begin{tabular}{|l|} 
Kodak Polychrome \\
Graphics Sword \\
Excel Regenerator, \\
Kodak Polychrome \\
Graphics 956 Nega- \\
tive Developer \\
\end{tabular} \\
\hline $\begin{array}{l}\text { Sodium } \\
\text { hydroxide }\end{array}$ & Y & - & - & - & - & - & $\begin{array}{l}\text { Kodak Polychrome } \\
\text { Graphics Sword } \\
\text { Excel Regenerator, }\end{array}$ \\
\hline $\begin{array}{l}\text { Triethanol- } \\
\text { amine }\end{array}$ & Y & - & $\begin{array}{l}\text { Respiratory } \\
\text { Sensitizer§ }\end{array}$ & - & - & Combustible & $\begin{array}{l}\text { Kodak Versamark } \\
\text { FD1040 IR Black } \\
\text { Ink }\end{array}$ \\
\hline
\end{tabular}


Table 2. Potential health hazards of chemicals found on safety data sheets (con't)

\begin{tabular}{|c|c|c|c|c|c|c|c|}
\hline Chemical & $\begin{array}{c}\text { Mucus } \\
\text { Membrane } \\
\text { Irritation }\end{array}$ & $\begin{array}{c}\text { Carcinogen } \\
\text { Rating* }\end{array}$ & $\begin{array}{c}\text { Asthmagen } \\
\text { Type }\end{array}$ & Skin $\dagger$ & $\begin{array}{c}\text { CNS } \\
\text { Effects }\end{array}$ & $\begin{array}{c}\text { Explosive } \\
\text { Hazard }\end{array}$ & Where Found \\
\hline $\begin{array}{c}\text { 2-Dimethyl- } \\
\text { aminoethanol }\end{array}$ & $\mathrm{Y}$ & - & $\begin{array}{c}\text { Respiratory } \\
\text { Sensitizer§ }\end{array}$ & $\mathrm{Y}$ & $\mathrm{Y}$ & Combustible & $\begin{array}{l}\text { Kodak Versamark } \\
\text { FD1040 IR Black } \\
\text { Ink }\end{array}$ \\
\hline
\end{tabular}

Note: $\mathrm{Y}=$ yes; $\mathrm{CNS}=$ central nervous system; ${ }^{\circ} \mathrm{C}=\mathrm{Celsius}$; “_"=indicates not applicable or lack of information.

*Categories of carcinogenicity are: Group 1: carcinogenic to humans; Group 2A: probably carcinogenic to humans; Group 2B: possibly carcinogenic to humans; Group 3: not classifiable as a carcinogen to humans due to a lack of studies; Group 4: probably not carcinogenic to humans. Groups listed above are based on data from the International Agency for Research on Cancer and the American Conference of Governmental Industrial Hygienists [IARC 2016, ACGIH 2015].

$\uparrow$ Asthmagen type is based on data published by the Association of Occupational and Environmental Clinics [AOEC 2012]. $\$$ Skin designation indicates chemicals that are capable of being absorbed across the skin.

$\S$ Respiratory sensitizers are materials that can cause an immune response and adverse respiratory effects, even at low levels of exposure.

TRADS indicates chemicals that can cause irritant induced asthma and Reactive Airways Dysfunction Syndrome. 
This page left intentionally blank 
Keywords: NAICS 323111: printing, Legionella, volatile organic compounds (VOCs), solvents, and Legionnaires' disease. 
The Health Hazard Evaluation Program investigates possible health hazards in the workplace under the authority of the Occupational Safety and Health Act of 1970 (29 U.S.C. § 669(a) (6)). The Health Hazard Evaluation Program also provides, upon request, technical assistance to federal, state, and local agencies to invest igate occupational health hazards and to prevent occupational disease or injury. Regulations guiding the Program can be found in Title 42, Code of Federal Regulations, Part 85; Requests for Health Hazard Evaluations (42 CPR Part 85).

\section{Disclaimer}

The recommendations in this report are made on the basis of the findings at the workplace evaluated and may not be applicable to other workplaces.

Mention of any company or product in this report does not constitute endorsement by the National Institute for Occupational Safety and Health (NIOSH).

Citations to Web sites external to N1OSH do not constitute NIOSH endorsement of the sponsoring organizations or their programs or products. NIOSH is not responsible for the content of these Web sites. All Web addresses referenced in this document were accessible as of the publication date.

\section{Acknowledgments}

Desktop Publisher: Tia McClelland

\section{Availability of Report}

Copies of this report have been sent to the employer, employees, and union at the facility. The state and local health department and the Occupational Safety and Health Administration Regional Office have also received a copy. This report is not copyrighted and may be freely reproduced.

This report is available at http://www.cdc.gov/niosh/hhe/reports/pdfs/2015-0065-3252.pdf.

All other HHE Reports may be found at http://www2a.cdc.gov/hhe/search.asp

\section{Recommended citation for this report:}

NIOSH [2016]. Health hazard evaluation report: evaluation of Legionnaires' disease risk and other health hazards at an offset printing company. By Casey M, Hawley B. Morgantown, WV: U.S. Department of Health and Human Services, Centers for Disease Control and Prevention, National Institute for Occupational Safety and Health, NIOSH HHE Report No. 2015-0065-3252. 
Delivering on the Nation's promise:

Safety and health at work for all people through research and prevention

To receive documents or other information about occupational safety and health topics, contact NIOSH

Telephone: 1-800-CDC-INFO (1-800-232-4636)

TTY: 1-888-232-6348

email: cdcinfo@cdc.gov

or visit the NIOSH website at http://www.cdc.gov/niosh

SAFER • HEALTHIER • PEOPLE ${ }^{\text {TM }}$ 